\title{
An approach to the phenomenology of the disease
}

\author{
Carlos Alva-Espinosa
}

Cardiology outpatient clinic, Hospital Ángeles del Pedregal, Mexico City, Mexico

\begin{abstract}
Modern medicine has undergone technological progress, undoubtedly with better results, but the doctor-patient relationship has been undermined in its most important aspect, human contact. The patient experiences and confronts in solitude his adverse experience. This experience is complex, not only are the symptoms of the disease, they also include disability, isolation, fear, dependence and sometimes guilt. Phenomenology attaches a paramount importance to the data in the consciousness of the patient, as facts given with absolute value. The purpose of this paper is to deepen the experience of the healthy adult individual who is ill. The better understanding of this phenomenology of the patient by the physician and the health personnel, can favor a better efficiency, empathy and compassion in their care.
\end{abstract}

KEY WORDS: Phenomenology. Disease. Experience. Symptoms.

\section{Introduction}

All patients suffering from a disease with symptoms, which are the majority (there are some diseases or disease stages where patients do not experience symptoms; for example, some patients with systemic arterial hypertension are asymptomatic), have, according to Lifshitz', some type of the following experiences: pain, fever, weakness, oppression, dizziness, vertigo, anxiety or shortness of breath; but they also experience disability to a greater or lesser degree, and can perceive a threat to their own selves as well. Given that disease can get complicated, the threat of dying because of disease is present. In that who suffer from it, awareness is on the symptom; for example, in painful hip, that what Pedro Laín Entralgo ${ }^{2}$ refers to as "body suction", in our example, "suctioned by the pain in the hip". In addition, some individuals, according to Hernández Bayona ${ }^{3}$, experience guilt and a need for expiation. They feel responsible for that what is happening to them; for example, a chronic smoker facing a lung cancer.

In brief, together with Estrada ${ }^{4}$, we can talk of the heaviness of suffering in the individual beset by disease.

Modern medicine has experienced great technological progress by means of uncountable diagnostic machines, undoubtedly with better outcomes, but the doctor-patient relationship has been undermined at its most important aspect: human contact. The CT scanner or the magnetic resonance tests are interposed between the doctor and his/her patient. The doctor orders a specialized study after a brief interrogatory and, at the next visit, already with study results, he/ she will explain what's going on; meanwhile, the patient continues the lonesome experience of his/her disease, and now with fear and anxiety for whatever it may occur to him/her during the study. For the sake of technological efficiency, patient experiences tend to be forgotten. A phenomenological approach to

\footnotetext{
Correspondence:

Carlos Alva-Espinosa

Camino a Santa Teresa, 1055, consultorio 201

Col. Héroes de Padierna, Del. Magdalena Contreras Date of reception: 20-11-2016

C.P. 10700, Ciudad de México, México

Date of reception: $20-11-2016$

Gac Med Mex. 2017;153:583-585

Contents available at PubMed

E-mail: carlosalvaespinosa@yahoo.com.mx

DOI://dx.doi.org/10.24875/GMM.M18000049

www.gacetamedicademexico.com
} 
disease might help to recover the importance of the doctor-patient relationship.

\section{Focus}

The experience of disease involves the intimate relationship between body and consciousness of the meaning given to the symptom and its relationship with the subject that experiences it and the world that surrounds him/her. Nothing is more mysterious to man, than the thickness of his own body ${ }^{5}$, particularly when it falls ill.

A phenomenological approach, understood as the analysis of the patient experiences within his/her consciousness, is necessary. Since these contents occur within the consciousness, according to Husserl ${ }^{6,7}$, not only are they real and intentional, but they are absolute contents as well; in other words, they are pure consciousness phenomena, which we'll see later in more detail.

Thus, the purpose of this work is to delve into the phenomenological experience of the adult healthy individual who gets sick, in order to obtain a better understanding on what he/she experiences and thereby strengthen inter-subject useful communication and empathy in the relationship of the healthcare professional with the patient.

In the review of the literature about phenomenology and disease there are several related articles, but most of them address mental disorders ${ }^{8-14}$. In this work, only situations where adult individuals preserve their mental faculties intact and experience serious non-psychiatric symptoms will be considered.

\section{How to phenomenologically approach disease}

A previous requirement for a phenomenological approach to disease consists in going deep into the idea of phenomenon. "Phenomenon" defines the experience of the self in its consciousness and nothing more, but also nothing less ${ }^{7}$. This experience is complex and its contents can originate in the exterior of the subject, in the real world (for example, perceiving the operation room with all its components, including the surgeon), or in his/ her interior (let's say, his/her thoughts and emotions). In the process of consciousness, phenomena generally include both sources: internal and external. Either way, the focus in this article is directed to that what is given in the patient consciousness; that what he/she experiences should be considered as what it is for him/herself, as a true and absolute fact, which doesn't mean there is an exact and true correspondence with external reality.

\section{Mind and body}

The experience of our own body teaches us to implant space in existence. "Being" body is to be tied to a certain world; we live, and our body is not, first of all, in space: it belongs to space ${ }^{15}$.

In the human being, consciousness has, under normal conditions, a close link with the body. Following Meralu-Ponty ${ }^{15}$, in the perception and interpretation of our own body, we'll have to say that it interprets itself. I am not in front of my body, I am in my body; or better yet, I am my body. In the mind-body relationship, the dichotomy disappears and can be summarized, for the purposes of this work, in the idea expressed by Ingold ${ }^{16}$ : body and mind are not two separate things, but two ways to describe the same thing, or rather, the same process, that is, the body-person activity within its surroundings.

The sick individual confronts his/her symptoms the same way he/she does with any adversity: as a whole, by means of a developing system ${ }^{16}$; i.e., he/she participates with his/her body, his/her mind and with the socio-cultural baggage he/she has at the moment of disease, but -and this is very important- from the moment the symptom appears, the individual reacts systemically by generating and creating a defense with that what he/ she is, with the tools he/she possesses at that moment, generating modifications in his/her being in interaction with his/her ailment, i.e., with him/herself, at that present he/she is living with and that appears to dilate. Although this defense is plastic and adapts to the new situation, it is generally unsuccessful or partially successful in terms of reestablishing balance (homeostasis), and tends to withdraw. That what this drawing back consists in is what we are going to review next.

\section{What is essential in the phenomenology of disease?}

In the phenomenology of disease, isolation, withdrawal of the self and solitude are essential. When the surroundings are the disease of one's own body, the link of consciousness with the body is exacerbated. If under normal conditions we know where are the parts of our body that accompany us, but only marginally, and we can, for example, drive the car thinking on the plan for the day, in other words, consciousness is somewhere else, it does direct the world outside the body and acts on it. Consciousness is always being aware of something and, in disease, awareness is directed towards the body, specifically, it draws back to the "aching" part of it. There is a steal of consciousness 
attention, which doesn't go to the exterior and only addresses the more immediate world: its own body. It is the existence of the self experiencing solitude with its body, which is itself as well. It is the experience of the jail in one's own consciousness. It is unable to leave to the world because it is surrounded by aching barriers of the body that claim for undivided attention, but the body, in combination with the mind, is not a simple cell, but an entire knot of past, present and future living significances that prepare an adaptive reorganization according to the new situation.

\section{Limitation or loss of consciousness freedom}

One cannot be free when will and consciousness are "kidnapped" by the phenomenon of pain or dyspnea. Consciousness is entirely occupied by pain, the site of pain and its emotional and cognitive repercussions. If at all, thought and will are free for moments, when the doctor's intervention is effective.

Under the negative sensations of the experience of disease, thoughts are restricted and have a circular trajectory on the experience of feeling sick, of being sick, unceasingly returning.

\section{Consequences}

There is, of course, variability in the phenomenology of disease in different individuals. It can vary depending on the structure of their personality, their history, and the culture they have been submerged in. However, Ingold ${ }^{17}$ indicates that regardless of differences, it is important to identify and bear in mind and to know as best we can the common and more relevant elements of the patient phenomenology, in order to more efficiently help him/her and, most importantly, to accompany him/her with more humanity, in the sense of authentic empathy.

For anyone who lives the experience of being ill, amidst suffering there is solitude; the patient lives his/ her symptoms feeling intensely lonely, and then threatened'. Health's integrity has already been savaged by symptoms, but in addition to experiencing them, the experience of a threatening uncertainty is generated: the cause of my condition, which I ignore, is it serious? Will my discomforts progress or will other worse appear? Can it become complicated? And even the terminal threat, the threat of nothingness: can I die? At the same time, he/she finds him/herself disabled, unable to work and, in extreme cases, unable of personal care and dependent on others. To this experience of disability and dependence, economic uncertainty can be added, as well as the thought that comes along: leaving the family in economic defenselessness.

Finally, the patient can attribute the responsibility of his/her disease to him/herself, for example, for having been or being a smoker or alcoholic. The phenomenon of guilty conscience and its derivatives, self-reproach and feelings of worthlessness, can overtake all the others and cause serious depression.

\section{Conclusions}

- Phenomenology confers paramount importance to data on patient consciousness, as given facts with absolute value.

- The patient confronts disease adversity by means of a developing system with all he/she has, with, in best case scenario, partial success.

- Suffering, solitude, threat, disability, limited freedom, dependence and sometimes guilt, make the experience of disease one of the worst in human experience.

- A better understanding of this patient phenomenology by the physician and by healthcare personnel can favor better efficiency, empathy and compassion on his/her care.

\section{References}

1. Lifhsitz A. La nueva clínica. México D.F.: Conacyt Intersistemas; 2014.

2. Laín Entralgo P. La medicina actual. Madrid: Triacastela; 2011.

3. Hernández Bayona G. Fenomenología de algunos síntomas de la depresión. Universitas Médica. 2007;48:228-40.

4. Estrada DA. Hacia una fenomenología de la enfermedad. latreia. 2012;25:277-86.

5. Le Bretón D. Antropología del cuerpo y modernidad. Buenos Aires: Nueva Visión; 2002. p. 7.

6. Husserl E. La idea de la fenomenología. México D.F.: Fondo de Cultura Económica; 2015. p. 34-56.

7. Husserl E. Investigaciones lógicas II. Madrid: Alianza; 2006. p. 763-77.

8. Cumming TB, Churilov L, Skoog I, et al. Little evidence for different phenomenology in poststroke depression. Acta Psychiatr Scand. 2010:121:424-30.

9. Narbona J. Depressive phenomenology at the outset of neuropaediatric diseases. Rev Neurol. 2014;58(Suppl 1):S 71-5.

10. Vingerhoets AJ, Van Huijgevoort M, Van Heck GL. Leisure sickness: a pilot study on its prevalence, phenomenology, and background. Psychother Psychosom. 2002;71:311-7.

11. Häfner H. Descriptive psychopathology, phenomenology, and the legacy of Karl Jaspers. Dialogues Clin Neurosci. 2015:17:19-29.

12. Matsnev El, Yakovleva IY, Tarasov IK, et al. Space motion sickness: phenomenology, countermeasures, and mechanisms. Aviat Space Environ Med. 1983;54:312-7.

13. Samudra N, Patel N, Womack KB, et al. Psychosis in Parkinson disease: a review of etiology, phenomenology, and management. Drugs Aging. 2016;33:855-63.

14. Zhou YR. The phenomenology of time: lived experiences of people with HIV/AIDS in China. Health (London). 2010;14:310-25.

15. Meralu-Ponty M. Fenomenología de la percepción. Barcelona: Planeta; 1985. p.165-70.

16. Ingold T. Tres en uno: cómo disolver las distinciones entre mente, cuerpo y cultura. En: Sánchez Criado T, editor. Tecnogénesis: la construcción técnica de las ecologías humanas. Madrid: AIBR; 2008. p. 1-35.

17. Ingold $\mathrm{T}$. The perception of the enviroment. Londres/NewYork: Routledge; 2000. p. 406-19. 